\title{
Methods of Abortion in First and Second Trimester
}

\author{
Li Min Lim, Kuldip Singh \\ Department of Obstetrics and Gynaecology, National University Hospital, Singapore City, Singapore \\ Email: obgkuldi@nus.edu.sg
}

Received 21 August 2014; revised 20 September 2014; accepted 15 October 2014

Copyright (C) 2014 by authors and Scientific Research Publishing Inc.

This work is licensed under the Creative Commons Attribution International License (CC BY). http://creativecommons.org/licenses/by/4.0/

(c) (i)

Open Access

\begin{abstract}
Background: Medical and surgical methods are available for abortions in both the first and second trimester. Aim: To review the evidence base and current recommendations for available methods of abortions in first and second trimesters. Methods: Extensive literature search and review of available guidelines were done. Results: In the first trimester, medical methods are recommended below 7 weeks gestation while vacuum aspiration is an appropriate method between 7 to 12 weeks gestation. In the second trimester, the three methods of abortion available are dilatation and evacuation, intrauterine instillation of abortifacients and administration of systemic abortifacients. Conclusion: The choice of techniques depends on many factors including uterine volume, operator experience, patient preference, medical history and indication for abortion.
\end{abstract}

\section{Keywords}

Abortion, Surgical, Medical, Trimester

\section{Introduction}

Abortion is one of the most commonly performed procedures in gynaecological departments worldwide. The latest estimated worldwide rate for abortion in 2008 is 28 per 1000 women aged 15 to 44 years old [1]. Worldwide, an estimate of 42 million induced abortions takes place every year [2]. Medical and surgical methods are available for both first and second trimester abortions. The choice of technique for uterine evacuation depends on many factors including uterine volume, patient's gynaecological history, abortion indication and operator experience. In Singapore, abortions are legal up till 24 weeks gestation. In general, indications for abortions include social reasons and medical reasons such as lethal fetal anomalies.

In this chapter, we will be reviewing the various methods of abortion available in both the first and second trimesters. Women should be informed that infection may occur after medical or surgical abortion and universal antibiotic prophylaxis is recommended [3]. The following regimens are suitable for peri-abortion antibiotic 
prophylaxis: azithromycin 1 gram (g) orally on the day of abortion or doxycycline 100 milligram (mg) orally twice daily for 7 days starting on the day of abortion, plus metronidazole $1 \mathrm{~g}$ rectally or $800 \mathrm{mg}$ orally prior to or at the time of abortion. Discussion on the management of missed abortion is beyond the scope of this review.

\section{First Trimester Abortion}

In the first trimester, surgical methods via vacuum aspiration or medical methods using combined mifepristone and prostaglandin regimens or prostaglandin-only regimens are available. Both methods are safe and effective approaches for appropriately selected patients. For women presenting at less than 7 weeks gestation, surgical vacuum aspirations are three times more likely to fail to remove the gestational sac compared to those performed between 7 to 12 weeks gestation [3]. Medical abortion is therefore usually considered at these earlier stages of pregnancy. Between 7 to 14 weeks gestation, vacuum aspiration is an appropriate method though individual specialists may prefer to offer medical abortion at gestation above 12 weeks. Comparison of the characteristerics and complications of both methods is detailed in Table 1.

Medical abortion (also known as medication abortion) involves the use of medications to terminate a pregnancy. Mifepristone, combined with misoprostol, is the most commonly used medical abortion regimen in the United States and Western Europe [4]. Mifepristone acts as an antiprogestin by binding to the progesterone receptor with an affinity greater than progesterone itself but does not activate the receptor. Studies have shown that uterine contractility and the sensitivity of the myometrium to the stimulatory effects of exogenous prostaglandins increases 5-fold at 24 - 36 hours after administration [5]. Misoprostol is an inexpensive prostaglandin E1 analogue in a tablet form that is stable at room temperature. Studies have shown that misoprostol is more effective when administered vaginally rather than orally [6]. In addition, side effects such as vomiting and diarrhea were reported more frequently by women who received oral misoprostol as compared to those who received vaginal misoprostol [6].

The FDA-approved regimen includes mifepristone $600 \mathrm{mg}$ orally, followed approximately 48 hours later by a prostaglandin analogue, usually misoprostol 400 microgram (mcg) orally [4]. The efficacy of the FDA-approved regimen is approximately $92 \%$ for women with gestations up to 7 weeks [7]. The patient should have a follow-up visit approximately 14 days after mifepristone administration to evaluate whether the women has had a confirmed abortion. However, additional research has shown that the regimen could be altered to improve medical abortion in terms of expense, safety, speed and adverse effects. A Cochrane review has shown that the dose of mifepristone can be lowered to $200 \mathrm{mg}$ without significantly decreasing the method effectiveness [8]. Vaginal, buccal and sublingual routes of misoprostol administration also appear to increase efficacy, decrease continuing pregnancy rates and increase the gestational age range for use as compared with the FDA-approved regimen [9]. Besides, a 6- to 8-hour interval between mifepristone administration and vaginal misoprostol administration has been shown to be as effective as a 24-hour interval and also results in significantly fewer adverse effects [10].

In countries where mifepristone is not available, a misoprostol-only regimen can be used for first trimester medical abortion. The regimen includes a loading dose of $800 \mathrm{mcg}$ of misoprostol given vaginally, followed by three further doses of $400 \mathrm{mcg}$ of misoprostol given at three hourly intervals [11]. However, misoprostol-only medical abortion regimens are significantly less effective than those that use a combination of mifepristone and misoprostol, with an 88\% efficacy with misoprostol-only regimen in abortions up to 8 weeks gestation [12]. Prostaglandins used alone also seem to be less effective and more painful compared to surgical first-trimester

Table 1. Characteristics of methods of first trimester abortion.

\begin{tabular}{|c|c|c|c|}
\hline & Efficacy & Safety & Complications \\
\hline $\begin{array}{l}\text { Medical } \\
\text { abortion }\end{array}$ & $\begin{array}{l}\text { 92\% with mifepristone plus } \\
\text { misoprostol regime } \\
\text { (up to } 7 \text { weeks); } 96 \% \text { with } \\
\text { misoprostol-only regime } \\
\text { (up to } 8 \text { weeks) }\end{array}$ & $\begin{array}{l}\text { A 6- to 8-hour interval between } \\
\text { mifepristone administration and } \\
\text { vaginal misoprostol administration } \\
\text { has been shown to be as effective } \\
\text { as a 24-hour interval and results } \\
\text { in significantly fewer adverse effects. }\end{array}$ & $\begin{array}{l}\text { Gastrointestinal discomfort, abdominal pain, } \\
\text { excessive vaginal bleeding, headache, dizziness } \\
\text { and fatigue, incomplete abortion or continuing } \\
\text { pregnancy requiring surgical evacuation }\end{array}$ \\
\hline $\begin{array}{l}\text { Surgical } \\
\text { abortion }\end{array}$ & $\begin{array}{c}98 \% \text { - 99\% with } \\
\text { vacuum aspiration }\end{array}$ & $\begin{array}{l}\text { Cervical priming prior to surgical } \\
\text { evacuation reduces the risks of } \\
\text { cervical injury by making the } \\
\text { cervix softer and easier to dilate. }\end{array}$ & $\begin{array}{l}\text { Bleeding requiring transfusion, uterine perforation, } \\
\text { cervical trauma, uterine rupture, infection, } \\
\text { continuation of pregnancy and incomplete } \\
\text { abortion requiring further intervention }\end{array}$ \\
\hline
\end{tabular}


abortion [13]. A prospective study of abortions in gestations up to 8 weeks has shown that the misoprostol-only regimen has a complete abortion rate of $84.7 \%$ and $96.0 \%$ at 15 days and 43 days after initial administration of vaginal misoprostol [11]. The mean duration of bleeding was 11.7 days [11]. In countries where mifepristone is not available, this regimen can serve as a viable alternative.

Bleeding and cramping will be experienced by most women undergoing medical abortion and are necessary for the process to occur. Common side effects associated with medical abortion include gastrointestinal discomfort (nausea, vomiting, diarrhoea), abdominal pain, excessive vaginal bleeding, headache, dizziness and fatigue. Surgical evacuation may eventually be required for incomplete abortion or continuing pregnancy.

Surgical termination of pregnancy in the first trimester involves vacuum aspiration using a suction device. Dilation of the cervix is usually necessary to allow insertion of instruments and removal of bulky uterine contents. Cervical priming prior to surgical evacuation reduces the risks of cervical injury by making the cervix softer and easier to dilate [14]. A number of effective methods available include osmotic dilators, antiprogesterone and prostaglandins such as misoprostol [14]. Osmotic dilators are inserted into the cervix and they swell gradually to prepare the cervix prior to surgical termination. This process requires a long latent period of 8 to 10 hours and is associated with the risk of infection [14]. Antiprogesterone such as mifepristone also requires a long latent period of 24 to 36 hours for it to be effective and has been associated with incomplete abortion and vaginal bleeding [14].

Prostaglandins remain the most widely used method of cervical preparation prior to vacuum aspiration. Misoprostol has been shown to be equally or more efficacious compared to osmotic dilators or mifepristone [14]. It is also more widely used compared to gemeprost, another prostaglandin analogue, as gemeprost is expensive, relatively unstable and requires refrigeration for storage [14]. Both oral and vaginal routes of administration of misoprostol have been shown to be equally effective in preinduction cervical ripening prior to first trimester pregnancy termination [14] [15]. The minimal evacuation interval should be at least 3 hours for successful pre-abortion cervical priming and the optimal dosage is $400 \mathrm{mcg}$ intravaginal misoprostol [16]-[18]. Increasing the time interval beyond three hours did not confer any additional advantage on the rate of successful cervical dilatation but was instead associated with an increase in side effects such as vaginal bleeding, lower abdominal pain and the appearance of products of conception at the cervical os [17]. The 400mcg dose of intravaginal misoprostol is recommended as it has lesser side effects such as abdominal pain and fever compared to the 600 and $800 \mathrm{mcg}$ doses [16] [18] [19]. There has even been a case report of malignant hyperthermia after a 600 mcg vaginal misoprostol was used for cervical priming [20]. There was no significant difference among the 400, 600 and 800 mcg dosage groups with respect to achieving cervical dilation of at least $8 \mathrm{~mm}$, whereas the success rate of the 200 mcg group was significantly lower than that of the 400 mcg group [19].

Curettage can then be performed using either manual or electric vacuum aspiration or sharp curettage. The manual vacuum aspirator is a hand-operated syringe in which vacuum is produced retracting a plunger. In electric vacuum aspiration, a rigid suction curette is inserted into the uterine cavity before suction is applied using an aspiration device. A systematic review reported no significant differences in complete abortion rates or patient satisfaction between both methods for termination of pregnancy at less than 10 weeks gestation [21]. Compared to sharp curettage, vacuum aspiration was associated with a statistically significant decrease in blood loss, pain and duration of procedure. There was otherwise no difference in need for re-evacuation or severe complications such as uterine perforation or sepsis [22]. Sharp curettage however can be used to check the uterine cavity for retained tissue at the end of the procedure.

First trimester surgical termination of pregnancy has an efficacy rate of 98\% to 99\% [23]. Surgical termination of pregnancy does not require hospitalization except in women with medical or surgical disorders that place them at higher surgical risk. Women should be adequately counselled about associated complications of the procedure and proper consent should be taken. Complications associated with surgical method of abortion include bleeding requiring transfusion, uterine perforation, cervical trauma, uterine rupture, infection, continuation of pregnancy and incomplete abortion requiring further intervention.

\section{Second Trimester Abortion}

There are three methods available for second trimester pregnancy termination: dilatation and evacuation, intrauterine (either the intra-amniotic cavity or the extraovular space) instillation of abortifacients and administration of systemic abortifacients. Comparison of the characteristerics and complications of each method is detailed in Table 2. 
Table 2. Characteristics of methods of second trimester abortion.

\begin{tabular}{|c|c|c|c|}
\hline & Efficacy & Safety & Complications \\
\hline $\begin{array}{c}\text { Dilatation and } \\
\text { evacuation }\end{array}$ & $\begin{array}{l}\text { 99\% successful } \\
\text { abortion rate [32] }\end{array}$ & $\begin{array}{l}\text { Complications are less frequent in earlier gestation. } \\
\text { The preferred technique of cervical dilatation is } \\
\text { to use multiple osmotic dilators. }\end{array}$ & $\begin{array}{l}\text { Cervical laceration, hemorrhage, } \\
\text { uterine perforation, infection, } \\
\text { incomplete abortion requiring } \\
\text { repeat evacuation (similar to first } \\
\text { trimester surgical abortion) }\end{array}$ \\
\hline $\begin{array}{l}\text { Intrauterine } \\
\text { instillation } \\
\text { of abortifacients }\end{array}$ & $\begin{array}{l}\text { 93\% successful } \\
\text { abortion rate [33] }\end{array}$ & $\begin{array}{l}\text { The location of the needle after insertion needs } \\
\text { to be confirmed by withdrawing a small amount of amniotic } \\
\text { fluid to prevent intravascular or intramyometrial infusion. }\end{array}$ & $\begin{array}{l}\text { Transient fetal survival, } \\
\text { gastrointestinal side effects, } \\
\text { hypernatremia, fluid overload }\end{array}$ \\
\hline $\begin{array}{l}\text { Administration } \\
\text { of systemic } \\
\text { abortifacients }\end{array}$ & $\begin{array}{c}\text { 97\% successful } \\
\text { abortion rate [28] }\end{array}$ & $\begin{array}{l}\text { Combined mifepristone and misoprostol regimen } \\
\text { has been shown to shorten the induction to } \\
\text { delivery time and decrease procedure-related } \\
\text { pain compared to prostaglandin only regimens. }\end{array}$ & $\begin{array}{c}\text { Fever, shivering, gastrointestinal } \\
\text { discomfort, retained products } \\
\text { of conception requiring surgical } \\
\text { evacuation }\end{array}$ \\
\hline
\end{tabular}

In the 1970s when abortion first became legal throughout United States, abortion after 12 weeks was generally accomplished in hospital by instillation of intra-amniotic hypertonic saline [24]. Hypertonic agents are infused into the intra-amniotic cavity or the extraovular space to induce contractions leading to evacuation of uterine contents. Two major agents used are prostaglandin F2-alpha and hypertonic saline. Intra-amniotic prostaglandin F2-alpha is effective but associated with transient fetal survival and significant gastrointestinal side effects. Hypertonic saline has the advantage of causing fetal death but the duration of the procedure can be prolonged with possible side effects such as hypernatremia and fluid overload [24].

Dilatation and evacuation has been shown to have half the rate of serious complications compared to instillation of abortifacients [25]. Second-trimester extraction requires dilation of the cervix and this technique involves an increased risk of cervical laceration and hemorrhage. It can be carried out using multiple osmotic dilators or intravaginal prostaglandins for cervical ripening. A vacuum cannula or a forceps can then be used to extract the fetal parts depending on the gestational age. Suction curettage is performed to extract any remaining tissue after the evacuation and the surgeon should also examine the specimen to verify that all products of conception have been removed. It is important that dilatation and evacuation can only be undertaken by gynaecologists who are trained in the procedure and has the necessary instruments. Majority of second trimester abortions in the United States are carried out by dilatation and evacuation [26].

In view of the potential side-effects and complications of dilatation and evacuation as well as instillation of intra-amniotic agents, much research has been carried out for other alternative methods. Administration of systemic abortifacients is another commonly used method for second trimester termination of pregnancy. Combined mifepristone and misoprostol regimen has been shown to shorten the induction to delivery time [27] and decrease procedure-related pain compared to prostaglandin only regimens. Mifepristone can be administered orally or vaginally. A suitable regimen would be oral mifepristone $200 \mathrm{mg}$ followed 24 - 36 hours later by intravaginal prostaglandins (800 mcg intravaginally followed by $400 \mathrm{mcg}$ orally or intravaginally at 3-hourly intervals up to a maximum of 4 doses) [28]. This regimen has been shown to have a 97\% successful abortion rate [28]. In the event of non-availability of mifepristone in certain countries, prostaglandin only regimens may be used. Misoprostol, a prostaglandin E1 analogue, is also commonly used as a single agent for second trimester medical abortion in many parts of the world. A recommended regimen is the administration of $400 \mathrm{mcg}$ of misoprostol vaginally every 3 to 4 hours with a maximum of 5 doses [29]. The vaginal route has been shown to be more effective than the oral route with a shorter induction-to-delivery interval [30]. Compared to instillation of intrauterine abortifacients such as prostaglandin F2-alpha, vaginal misoprostol has been shown to result in a significantly shorter mean induction-to-abortion interval though the successful abortion rates at 24 and 48 hours were not statistically significant [31]. Fever and shivering however were more common with vaginal misoprostol [31].

The primary factors in choosing a particular technique are the volume of intrauterine tissue, the experience of the surgeon and patient preference. Although use of abortifacients does not require a skilled operator, gynaecologists who use non-surgical methods must be prepared to employ surgical techniques of uterine evacuation when there are retained products of conception. 


\section{Conclusion}

Medical and surgical methods are available for both first and second trimester abortions. In the first trimester, medical methods are recommended for early gestations before 7 weeks. Vacuum aspiration is suitable for abortions at 7 to 12 weeks gestation. In the second trimester, dilatation and evacuation as well as systemic or intrauterine instillation of abortifacients are available techniques. The choice of techniques largely depends on the gestational age, surgeon expertise and patient preference. Most importantly, women should be adequately counselled on all their options available as well as the associated risks and benefits so as to arrive at an informed decision.

\section{Acknowledgements}

The authors would like to thank the Department of Obstetrics and Gynaecology, National University Hospital, Singapore for their support.

\section{References}

[1] Sedgh, G., Singh, S., Shah, I.H., et al. (2012) Induced Abortion: Incidence and Trends Worldwide from 1995 to 2008. The Lancet, 379, 625-632. http://dx.doi.org/10.1016/S0140-6736(11)61786-8

[2] Singh, K. and Fong, Y.F. (2000) Preparation of the Cervix for Surgical Termination of Pregnancy in the First Trimester. Human Reproduction Update, 6, 442-448. http://dx.doi.org/10.1093/humupd/6.5.442

[3] Royal College of Obstetricians and Gynaecologists (2011) The Care of Women Requesting Induced Abortion. Evidence-Based Clinical Guideline Number 7, RCOG, London.

[4] American College of Obstetricians and Gynecologists (2014) Practice Bulletin No. 143: Medical Management of First-Trimester Abortion. Obstetrics \& Gynecology, 123, 676-692. http://dx.doi.org/10.1097/01.AOG.0000444454.67279.7d

[5] Swahn, M.L. and Bygdeman, M. (1988) The Effect of the Antiprogestin RU 486 on Uterine Contractility and Sensitivity to Prostaglandin and Oxytocin. British Journal of Obstetrics and Gynaecology, 95, 126-134. http://dx.doi.org/10.1111/j.1471-0528.1988.tb06840.x

[6] El-Refaey, H., Rajasekar, D., Abdalla, M., et al. (1995) Induction of Abortion with Mifepristone (RU 486) and Oral or Vaginal Misoprostol. The New England Journal of Medicine, 332, 983-987. http://dx.doi.org/10.1056/NEJM199504133321502

[7] Spitz, I.M., Bardin, C.W., Benton, L. and Robbins, A. (1998) Early Pregnancy Termination with Mifepristone and Misoprostol in the United States. The New England Journal of Medicine, 338, 1241-1247. http://dx.doi.org/10.1056/NEJM199804303381801

[8] Kulier, R., Kapp, N., Gülmezoglu, A.M., Hofmeyr, G.J., Cheng, L. and Campana, A. (2011) Medical Methods for First Trimester Abortion (Review). Cochrane Database of Systematic Reviews, 11, Article ID: CD002855.

[9] Schaff, E.A. (2010) Mifepristone: Ten Years Later. Contraception, 81, 1-7. http://dx.doi.org/10.1016/j.contraception.2009.08.004

[10] Creinin, M.D., Fox, M.C., Teal, S., Chen, A., Schaff, E.A. and Meyn, L.A. (2004) MOD Study Trial Group. A Randomized Comparison of Misoprostol 6 to 8 Hours versus 24 Hours after Mifepristone for Abortion. Obstetrics \& Gynecology, 103, 851-859. http://dx.doi.org/10.1097/01.AOG.0000124271.23499.84

[11] Singh, K., Fong, Y.F. and Dong, F. (2003) A Viable Alternative to Surgical Vacuum Aspiration: Repeated Doses of Intravaginal Misoprostol over 9 Hours for Medical Termination of Pregnancies up to Eight Weeks. BJOG: An International Journal of Obstetrics \& Gynaecology, 110, 175-180. http://dx.doi.org/10.1046/j.1471-0528.2003.02225.x

[12] Jain, J.K., Dutton, C., Harwood, B., Meckstroth, K.R. and Mishell Jr., D.R. (2002) A Prospective Randomized, Double-Blinded, Placebo-Controlled Trial Comparing Mifepristone and Vaginal Misoprostol to Vaginal Misoprostol Alone for Elective Termination of Early Pregnancy. Human Reproduction, 17, 1477-1482. http://dx.doi.org/10.1093/humrep/17.6.1477

[13] Say, L., Kulier, R., Gülmezoglu, M. and Campana, A. (2005) Medical versus Surgical Methods for First Trimester Termination of Pregnancy. Cochrane Database of Systematic Reviews, Published Online.

[14] Singh, K. and Fong, Y.F. (2000) Preparation of the Cervix for Surgical Termination of Pregnancy in the First Trimester. Human Reproduction Update, 6, 442-448. http://dx.doi.org/10.1093/humupd/6.5.442

[15] Dey, M. (2013) Oral Misoprostol Is an Effective and Acceptable Alternative to Vaginal Administration for Cervical Priming before First Trimester Pregnancy Termination. Medical Journal Armed Forces India, 69, 27-30. http://dx.doi.org/10.1016/j.mjafi.2012.07.014 
[16] Singh, K., Fong, Y.F., Prasad, R.N. and Dong, F. (1999) Evacuation Interval after Vaginal Misoprostol for Preabortion Cervical Priming: A Randomized Trial. Obstetrics \& Gynecology, 94, 431-434.

[17] Fong, Y.F., Singh, K. and Prasad, R.N. (1998) A Comparative Study Using Two Dose Regimens (200 Microg or 400 Microg) of Vaginal Misoprostol for Pre-Operative Cervical Dilatation in First Trimester Nulliparae. BJOG: An International Journal of Obstetrics \& Gynaecology, 105, 413-417. http://dx.doi.org/10.1111/j.1471-0528.1998.tb10126.x

[18] Singh, K., Fong, Y.F., Prasad, R.N. and Dong, F. (1999) Vaginal Misoprostol for Pre-Abortion Cervical Priming: Is There an Optimal Evacuation Time Interval? BJOG: An International Journal of Obstetrics \& Gynaecology, 106, 266269. http://dx.doi.org/10.1111/j.1471-0528.1999.tb08241.x

[19] Singh, K., Fong, Y.F., Prasad, R.N. and Dong, F. (1998) Randomized Trial to Determine Optimal Dose of Vaginal Misoprostol for Preabortion Cervical Priming. Obstetrics \& Gynecology, 92, 795-798. http://dx.doi.org/10.1016/S0029-7844(98)00281-6

[20] Fong, Y.F., Singh, K. and Prasad, R.N. (1999) Severe Hyperthermia Following Use of Vaginal Misoprostol for PreOperative Cervical Priming. International Journal of Gynecology and Obstetrics, 64, 73-74. http://dx.doi.org/10.1016/S0020-7292(98)00151-9

[21] Wen, J., Cai, Q.Y., Deng, F. and Li, Y.P. (2008) Manual versus Electric Vacuum Aspiration for First-Trimester Abortion: A Systematic Review. BJOG: An International Journal of Obstetrics \& Gynaecology, 115, 5-13. http://dx.doi.org/10.1111/j.1471-0528.2007.01572.x

[22] Verkuyl, D.A. and Crowther, C.A. (1993) Suction v. Conventional Curettage in Incomplete Abortion. A Randomised Controlled Trial. South African Medical Journal, 83, 13-15.

[23] Ngo, T.D., Park, M.H. and Free, C. (2013) Safety and Effectiveness of Termination Services Performed by Doctors versus Midlevel Providers: A Systematic Review and Analysis. International Journal of Women's Health, 5, 9-17. http://dx.doi.org/10.2147/IJWH.S39627

[24] Stubblefield, P.G., Carr-Ellis, S. and Borgatta, L. (2004) Methods for Induced Abortion. Obstetrics \& Gynecology, 104, 174-185. http://dx.doi.org/10.1097/01.AOG.0000130842.21897.53

[25] Kafrissen, M.E., Schulz, K.F., Grimes, D.A. and Cates Jr., W. (1984) Midtrimester Abortion. Intra-Amniotic Instillation of Hyperosmolar Urea and Prostaglandin F2 $\alpha$ v Dilatation and Evacuation. JAMA, 251, 916-919. http://dx.doi.org/10.1001/jama.1984.03340310030014

[26] American College of Obstetricians and Gynecologists (2013) Practice Bulletin No. 135: Second-Trimester Abortion. Obstetrics \& Gynecology, 121, 1394-1406. http://dx.doi.org/10.1097/01.AOG.0000431056.79334.cC

[27] Kapp, N., Borgatta, L., Stubblefield, P., Vragovic, O. and Moreno, N. (2007) Mifepristone in Second-Trimester Medical Abortion: A Randomized Controlled Trial. Obstetrics \& Gynecology, 110, 1304-1310. http://dx.doi.org/10.1097/01.AOG.0000289577.32274.a5

[28] Ashok, P.W., Templeton, A., Wagaarachchi, P.T. and Flett, G.M. (2004) Midtrimester Medical Termination of Pregnancy: A Review of 1002 Consecutive Cases. Contraception, 69, 51-58. http://dx.doi.org/10.1016/j.contraception.2003.09.006

[29] Wong, K.S., Ngai, C.S., Yeo, E.L., Tang, L.C.H. and Ho, P.C. (2000) A Comparison of Two Regimens of Intravaginal Misoprostol for Termination of Second Trimester Pregnancy: A Randomized Comparative Trial. Human Reproduction, 15, 709-712. http://dx.doi.org/10.1093/humrep/15.3.709

[30] Dickinson, J.E. and Evans, S.F. (2003) A Comparison of Oral Misoprostol with Vaginal Misoprostol Administration in Second-Trimester Pregnancy Termination for Fetal Abnormality. Obstetrics \& Gynecology, 101, 1294-1299. http://dx.doi.org/10.1016/S0029-7844(03)00357-0

[31] Su, L.L., Biswas, A., Choolani, M., Kalaichelvan, V. and Singh, K. (2005) A Prospective, Randomized Comparison of Vaginal Misoprostol versus Intra-Amniotic Prostaglandins for Midtrimester Termination of Pregnancy. American Journal of Obstetrics \& Gynecology, 193, 1410-1414. http://dx.doi.org/10.1016/j.ajog.2005.02.082

[32] Peterson, W.F., Berry, F.N., Grace, M.R. and Gulbranson, C.L. (1983) Second-Trimester Abortion by Dilatation and Evacuation: An Analysis of 11,747 Cases. Obstetrics \& Gynecology, 62, 185-190.

[33] Embrey, M.P. and Hillier, K. (1971) Therapeutic Abortion by Intrauterine Instillation of Prostaglandins. British Medical Journal, 1, 588-590. http://dx.doi.org/10.1136/bmj.1.5749.588 
Scientific Research Publishing (SCIRP) is one of the largest Open Access journal publishers. It is currently publishing more than 200 open access, online, peer-reviewed journals covering a wide range of academic disciplines. SCIRP serves the worldwide academic communities and contributes to the progress and application of science with its publication.

Other selected journals from SCIRP are listed as below. Submit your manuscript to us via either submit@scirp.org or Online Submission Portal.
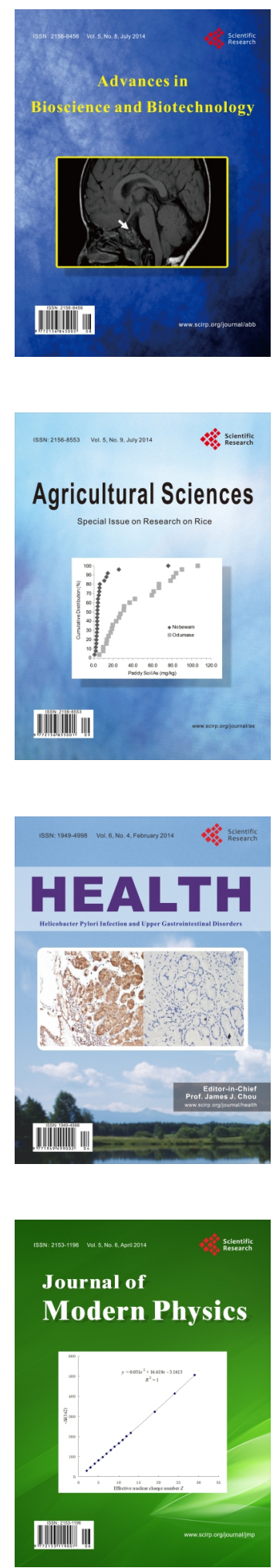
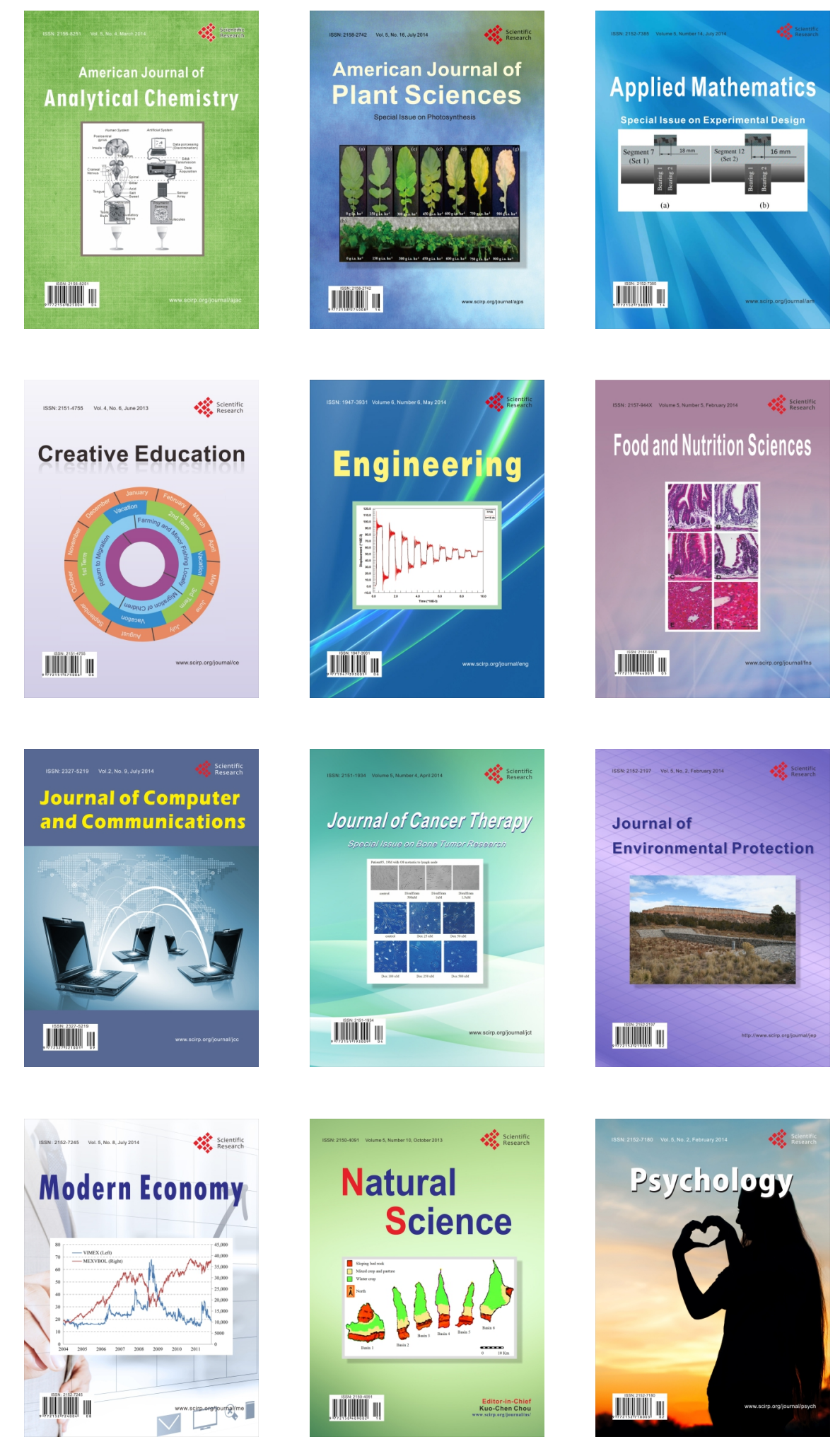